\title{
The deglaciation of Clyde Inlet, northeastern Baffin Island, Arctic Canada
}

\author{
JASON P. BRINER, ${ }^{1 *}$ IRINA OVEREEM, ${ }^{2 \dagger}$ GIFFORD MILLER $^{2}$ and ROBERT FINKEL ${ }^{3}$ \\ ${ }^{1}$ Geology Department, University at Buffalo, Buffalo, New York, USA \\ 2 Institute of Arctic and Alpine Research, University of Colorado, Boulder, Colorado, USA \\ ${ }^{3}$ Center for Accelerator Mass Spectrometry, Lawrence Livermore National Laboratory, Livermore, California, USA
}

\begin{abstract}
The behaviour of ice sheets as they retreated from their Last Glacial Maximum (LGM) positions provides insights into Lateglacial and early Holocene ice-sheet dynamics and climate change. The pattern of deglaciation of the Laurentide Ice Sheet (LIS) in arctic fiord landscapes can now be well dated using cosmogenic exposure dating. We use cosmogenic exposure and radiocarbon ages to constrain the deglaciation history of Clyde Inlet, a $120 \mathrm{~km}$ long fiord on northeastern Baffin Island. The LIS reached the continental shelf during the LGM, retreated from the coastal lowlands by $12.5 \pm 0.7 \mathrm{ka}(n=3)$, and from the fiord mouth by $11.7 \pm 2.2 \mathrm{ka}(n=4)$. Rapid retreat from the outer fiord occurred $10.3 \pm 1.3 \mathrm{ka}(n=6)$, with the terminus reaching the inner fiord shortly after $9.4 \mathrm{ka}$ $(n=2)$, where several moraine systems were deposited between ca. 9.4 and ca. $8.4 \mathrm{ka}$. These moraines represent fluctuations of the LIS during the warmest summers since the last interglaciation, and this suggests that the ice sheet was responding to increased snowfall. Before retreating from the head of Clyde Inlet, the LIS margin fluctuated at least twice between ca. 7.9 and ca. $8.5 \mathrm{ka}$, possibly in response to the 8.2 ka cold event. Copyright (C) 2006 John Wiley \& Sons, Ltd.
\end{abstract}

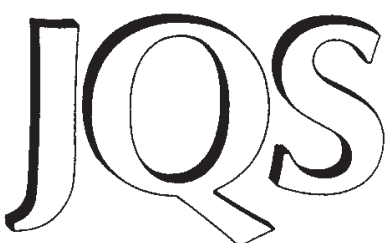

Journal of Quaternary Science

KEYWORDS: deglaciation; Laurentide; Ice Sheet; Baffin Island; cosmogenic exposure dating; radiocarbon dating.

\section{Introduction}

The retreat of the Laurentide Ice Sheet (LIS) following the Last Glacial Maximum (LGM) was spatially and temporally variable (e.g. Dyke et al., 2003). Stillstands and readvances during overall retreat provide insights into Lateglacial and early Holocene climate fluctuations and ice-sheet dynamics. For example, a widely traceable and prominent series of moraines at the fiord heads along eastern Baffin Island, arctic Canada (Baffinland Drift) represents readvances of the northeastern LIS between ca. 8000 and $9000{ }^{14}$ C yr BP (Ives and Andrews, 1963; Falconer et al., 1965; Andrews and Ives, 1978). Fiords along the northeastern coast of Baffin Island (Fig. 1) were thought to have remained ice-free during the Last Glacial Maximum (LGM; Dyke and Prest, 1987, vs. Steig et al., 1998; Dyke et al., 2002; Miller et al., 2002; Briner et al., 2005). However, recent evidence indicates that northeastern Baffin Island fiords were occupied

* Correspondence to: J. Briner, Geology Department, University at Buffalo, Buffalo, NY 14260, USA. E-mail: jbriner@buffalo.edu

${ }^{\dagger}$ Current address: Department of Civil Engineering and Geotechnology, Delft University of Technology, 2600 GA Delft, The Netherlands.

Contract/grant sponsor: National Science Foundation, Arctic Natural Sciences Program; contract/grant numbers: OPP-0004455, OPP-0138010.

Contract/grant sponsor: U.S. Department of Energy; contract/grant number: W-7405-Eng-48. with ice during the LGM (e.g. Briner et al., 2003, 2005). Studies have yet to investigate the deglaciation of northeastern Baffin Island fiords since this recent finding, and the pattern of ice retreat between the LGM and the early Holocene is not well known. However, understanding deglaciation in this region is important because it may be analogous to presently retreating outlet glaciers and ice streams of the Greenland Ice Sheet on the opposite side of Baffin Bay (Fig. 1).

Here, we report on the deglaciation and postglacial emergence history of Clyde Inlet (Fig. 1), a $120 \mathrm{~km}$ long fiord that was a major passageway for outlet glaciers and ice streams that drained the northeastern LIS during the LGM. Today, we have the advantage of cosmogenic exposure dating, which allows us to constrain the timing of deglaciation of the outer fiord regions, where fossiliferous raised marine deposits are scant. Cosmogenic exposure ages of moraine segments and sculpted bedrock and radiocarbon ages of raised marine deposits allow us to reconstruct the deglaciation from the mouth to the head of Clyde Inlet, which likely has a similar deglaciation history to dozens of other fiords along northeastern Baffin Island.

\section{Physiography of Clyde Inlet}

The Clyde Region of northeastern Baffin Island is centred around Clyde Inlet, a $120 \mathrm{~km}$ long fiord that stretches from 


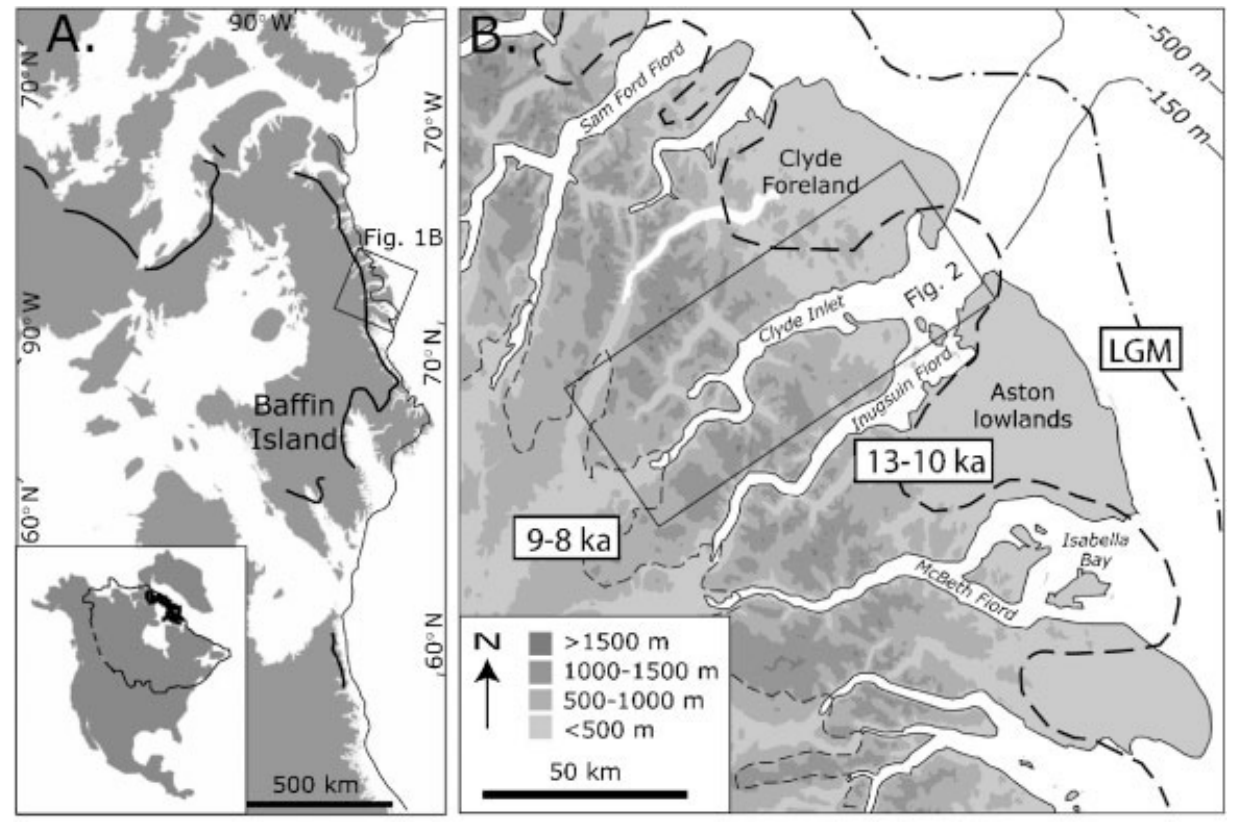

Figure 1 (A) Eastern Canadian Arctic showing Baffin Island and the extent of the Laurentide Ice Sheet during the Last Glacial Maximum (thin line, from Dyke et al., 2002) and during the Cockburn Substage (thick line, from Falconer et al., 1965). Inset shows the full extent of Laurentide Ice Sheet during the LGM. (B) The Clyde Region showing major fiords and coastal lowlands with various reconstructed ice limits

Baffin Island's interior plateau to the coastal lowlands adjacent to Baffin Bay (Fig. 2). The fiord reaches maximum depths of ca. $470 \mathrm{~m}$ in its middle section where it cuts through the highest portion of the eastern Canadian rim, which rises ca. 1000 to $1500 \mathrm{~m}$ above the fiord. The fiord widens toward its mouth (from $<10 \mathrm{~km}$ to $10-20 \mathrm{~km}$; Fig. 2) where the fiord bottom becomes irregular and shallower. Moraines are preserved along the outer ca. $40 \mathrm{~km}$ of the fiord and along the inner ca. $5 \mathrm{~km}$, but in between, owing to steeper topography, the moraine record is scant. During glacial maxima, LIS outlet glaciers that occupied outer Clyde Inlet flowed up tributary valleys as distributary lobes, damming lakes, depositing moraines and creating meltwater channels (Briner et al., 2005). Evidence for ice-marginal lakes includes shorelines, deltas and wave-cut platforms (Briner et al., 2005).

The Clyde River valley contains dozens of well-preserved moraine segments reflecting irregular deglaciation in the early Holocene. The lowermost Clyde River valley holds a rich record of raised marine features; several prominent deltas, ranging from 62 to $67 \mathrm{~m}$ a.s.l. can be tied to distinct ice limits

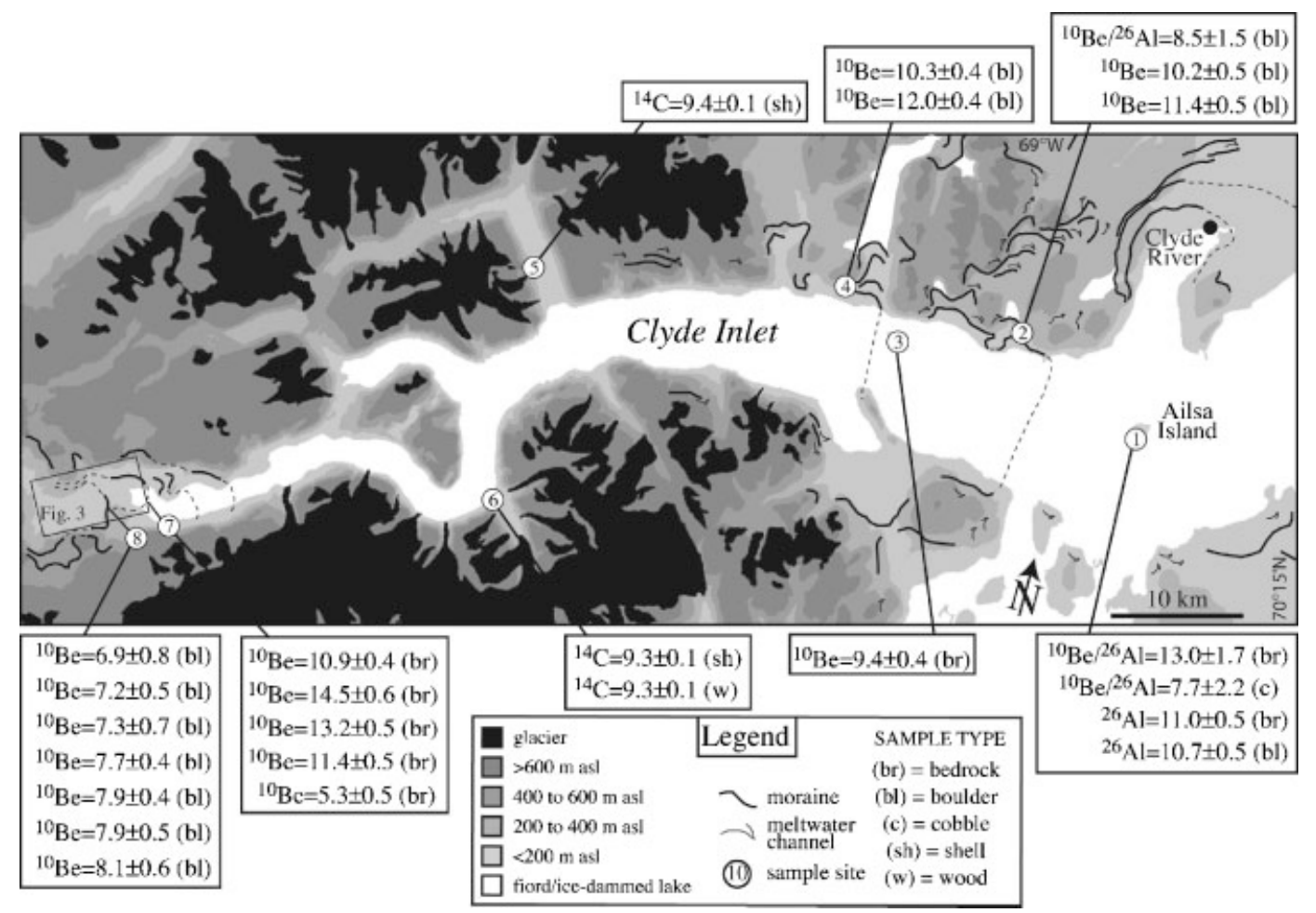

Figure 2 Clyde Inlet showing major glacial features. Cosmogenic and radiocarbon ages show the timing of retreat through Clyde Inlet. Radiocarbon ages are calibrated and corrected for the marine reservoir effect. Site numbers refer to ages in Tables 1 and 2 
(Fig. 2). The ice limits at the fiord head have previously been mapped as part of the Baffinland Drift belt, deposited between ca. 8000 and ca. $9000{ }^{14} \mathrm{C}$ yr BP during the Cockburn Substage across hundreds of kilometres (Andrews and Ives, 1978). Several distinct moraine segments at the fiord head define ice margins calving into Clyde Inlet, and several well-defined moraines lie farther inland from the fiord head. Moraine sequences and raised marine features at similar elevations occur at the heads of adjacent Inugsuin and Sam Ford fiords (Fig. 1; Løken, 1965; Smith, 1966). The Barnes Ice Cap rests on the interior Baffin Island plateau ca. $45 \mathrm{~km}$ up-fiord from the head of Clyde Inlet (Andrews and Barnett, 1979). The presence of Pleistocene ice at the base of the Barnes Ice Cap (Hooke, 1976) indicates that it is the final remnant of the LIS.

\section{Overview of the glacial history of the Clyde Region}

The glacial history of the Clyde and Aston lowlands, and of the summits of outer Clyde Inlet, has been the focus of recent research (Briner, 2003; Briner et al., 2003, 2005; Coulthard, 2003; Davis et al., 2006). Cosmogenic exposure dating, combined with ice-limit mapping updated from previous studies (Smith, 1965; Miller, 1976; Miller et al., 1977; Mode, 1980), has shown that cold-based, non-erosive Laurentide ice occupied most of the coastal lowlands during the LGM (Briner et al., 2005).

Plateaus and summits surrounding outer Clyde Inlet, ranging in elevation from $>600 \mathrm{~m}$ a.s.l. ca. $30 \mathrm{~km}$ from the fiord mouth to ca. $400 \mathrm{~m}$ a.s.l. at the fiord mouth, are highly weathered. The contrast in weathering features from low elevations to the surrounding summits has been studied in detail elsewhere (e.g. Boyer and Pheasant, 1974; Ives, 1978), and has been argued recently by Briner et al. $(2003,2006 a)$ to represent a shift in basal thermal regime from warm-based, erosive ice in the fiord to cold-based, protective ice at higher elevations. Lateral moraine segments at ca. 200 to 300 ma.s.l., which separate little-weathered bedrock surfaces below from intermediately and highly weathered bedrock surfaces above, were deposited during the last deglaciation. The youngest erratics on the summits along outer Clyde Inlet have cosmogenic exposure ages that indicate that the summits were deglaciated 11.5 to $13 \mathrm{ka}$ (Briner et al., 2003).

\section{Methods}

We report cosmogenic exposure ages from 22 samples, 12 new radiocarbon ages, and 8 previously published radiocarbon ages from the Clyde Inlet region. Samples for cosmogenic exposure dating were collected from moraine boulders, sculpted bedrock, cobbles and boulders perched on bedrock, and delta-top boulders. Samples were prepared at the University of Colorado Cosmogenic Isotope Laboratory (CUCIL) following procedures modified from Kohl and Nishiizumi (1992) and Bierman and Caffee (2001). Exposure ages were calculated using ${ }^{10} \mathrm{Be}$ and ${ }^{26} \mathrm{Al}$ production rates of 5.1 and 31.1 atoms $\mathrm{g}^{-1} \mathrm{yr}^{-1}$, respectively (Stone, 2000; Gosse and Stone, 2001). Site-specific production rates were corrected for elevation (Lal, 1991; Stone, 2000), topographic shielding and sample thickness. Because these samples are from high latitude $\left(\mathrm{ca} .70^{\circ} \mathrm{N}\right)$, radionuclide production rates are not influenced by time-dependent changes in the geomagnetic field. The ages reported here are not corrected for atmospheric pressure anomalies, but average low pressure over Baffin Bay may increase the production rates by ca. $2 \%$ (Stone, 2000). Where both ${ }^{10} \mathrm{Be}$ and ${ }^{26} \mathrm{Al}$ concentrations were measured, an uncertainty-weighted average exposure age was calculated. Ages reported here include only the one standard deviation accelerator mass spectrometry (AMS) measurement uncertainty. We report all ages assuming no significant surface erosion or snow shielding. Rock weathering in the region occurs slowly (Bierman et al., 1999), and most samples were collected from snow-free sites in May, when snow depths are greatest (Briner et al., 2005).

Radiocarbon ages (AMS) were obtained from marine bivalve and terrestrial organic samples and were calibrated using CALIB html version 5.0.1 (Stuiver et al., 2005; http:// radiocarbon.pa.qub.ac.uk/calib/). The mean age and one standard deviation were calculated by taking the midpoint of the one standard deviation age range reported in CALIB. Marine samples were calibrated using CALIB and were corrected for a local reservoir effect of $540 \mathrm{yr}$ obtained in this study (see below).

\section{Results and interpretations}

\section{Outer Clyde Inlet}

Boulders from lateral moraines and sculpted bedrock and perched erratics from islands in outer Clyde Inlet were sampled for cosmogenic exposure dating to establish when the LIS retreated from the mouth of the fiord (Fig. 2). Four samples obtained from the summit of Ailsa Island (42 $\mathrm{m}$ a.s.I.), which lies in the mouth of Clyde Inlet, average $11.7 \pm 2.2 \mathrm{ka}$ (Table 1; site 1, Fig. 2). These include two bedrock samples, one erratic cobble and one erratic boulder. The individual ages are scattered, for example, the cobble has an average ${ }^{26} \mathrm{Al} /{ }^{10} \mathrm{Be}$ age of $7.7 \pm 1.5 \mathrm{ka}$ and one bedrock sample has an average ${ }^{26} \mathrm{Al} /{ }^{10} \mathrm{Be}$ age of $13.0 \pm 0.4 \mathrm{ka}$ (Table 1$)$. The other two samples are closer in age at $11.0 \pm 0.5 \mathrm{ka}$ (bedrock) and $10.7 \pm 0.5 \mathrm{ka}$ (boulder). The bedrock samples come from striated surfaces, thus surface erosion since deglaciation at these sites is negligible.

Three boulders from a sharp-crested lateral moraine segment ca. $10 \mathrm{~km}$ up-valley from Ailsa Island yield an average age of $10.0 \pm 1.5$ ka (Table 1; site 2, Fig. 2). Similar to the Ailsa Island samples, there is scatter among the lateral moraine boulder ages, ranging from $8.5 \pm 0.2 \mathrm{ka}$ to $11.4 \pm 0.5 \mathrm{ka}$. One sample from $36 \mathrm{~m}$ a.s.l. atop a sculpted bedrock island ca. $18 \mathrm{~km}$ up-fiord from Ailsa Island has a ${ }^{10} \mathrm{Be}$ age of $9.4 \pm 0.4 \mathrm{ka}$ and $\mathrm{a}$ ${ }^{26} \mathrm{Al}$ age of $12.5 \pm 0.7 \mathrm{ka}$ (Table 1 ; site 3, Fig. 2). A second ${ }^{10} \mathrm{Be}$ age was obtained on the same sample, prepared at the University of Vermont cosmogenic isotope laboratory, as an inter-laboratory comparison between the Colorado and Vermont laboratories. The ${ }^{10} \mathrm{Be}$ age of $9.3 \pm 0.4 \mathrm{ka}$ (Table 1 ) supports the first ${ }^{10} \mathrm{Be}$ age, and suggests that the ${ }^{26} \mathrm{Al}$ age is too old. With few exceptions, the dozens of ${ }^{10} \mathrm{Be}$ and ${ }^{26} \mathrm{Al}$ age pairs obtained from the Clyde Region are concordant and show no systematic offset (Briner et al., 2005). Because the Ailsa Island sample is from ca. $10 \mathrm{~m}$ below the deglacial-aged marine limit its first exposure to the cosmic flux would have been partially shielded by water and thus its age is likely slightly younger than deglaciation. Two boulders from a moraine segment ca. $25 \mathrm{~km}$ up-fiord from Ailsa Island average 11.2 $1.2 \mathrm{ka}$ (Table 1; site 4, Fig. 2).

Two raised deltas help to establish the marine limit in outer Clyde Inlet. A 39 m a.s.I. delta near site 2 (Fig. 2) which, based 


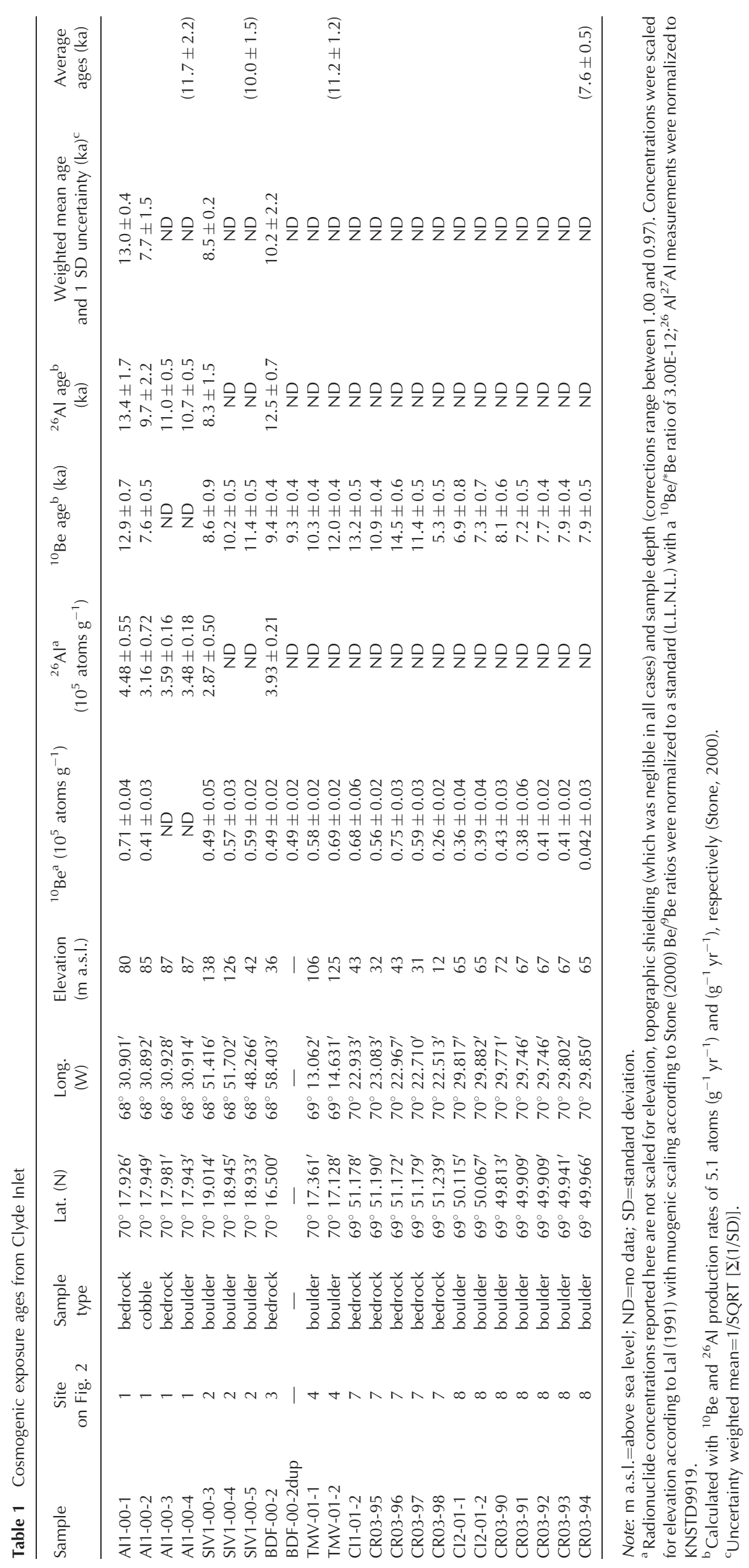


on morphostratigraphy, must be of very similar age to the lateral moraine at that site $(10.0 \pm 1.5 \mathrm{ka})$. Similarly, a $52 \mathrm{~m}$ a.s.I. delta is tied to the lateral moraine at site 4 (Fig. 2). No radiocarbon ages exist from elevations this high in outer Clyde Inlet, but these features can be constrained to ca. 10.0 to $11.7 \mathrm{ka}$ based on associations with the exposure age-dated glacial features.

\section{Middle Clyde Inlet}

Samples for cosmogenic exposure ages were not obtained from the middle section of Clyde Inlet because of the absence of moraines and islands in this steep and narrow section. However, radiocarbon ages were obtained from raised marine deposits from two sites in tributary valleys. Marine muds drape the valley floor up to ca. $52 \mathrm{~m}$ a.s.l. in a large tributary valley ca. $40 \mathrm{~km}$ up-fiord from Ailsa Island (site 5, Fig. 2). A paired Hiatella arctica from $38 \mathrm{~m}$ a.s.l. has a radiocarbon age of $8940 \pm 80{ }^{14} \mathrm{C}$ yr BP $\quad(9410 \pm 80 \mathrm{cal} . \mathrm{yr} \mathrm{BP}$; site 5, Fig. 2; Table 2). At a second site, ca. $55 \mathrm{~km}$ up-valley from Ailsa Island, within the narrow, steep, curved part of inner Clyde Inlet, a marine delta has emerged to $33 \mathrm{~m}$ a.s.I. (site 6, Fig. 2). A paired, Mya truncata from foreset beds yields a radiocarbon age of $8810 \pm 90{ }^{14} \mathrm{C}$ yr BP $(9270 \pm 120 \mathrm{cal} . \mathrm{yr} \mathrm{BP}$; site 6, Fig. 2; Table 2). A piece of wood from the same strata is $8270 \pm 40{ }^{14} \mathrm{C}$ yr BP $(9270 \pm 130$ cal. yr BP; Table 2$)$, indicating a reservoir age of Clyde Inlet of $540 \mathrm{yr}$, which we use in our reservoir-age corrections. It is unclear whether this delta represents the marine limit for this part of the fiord. Regardless, these two radiocarbon ages require the Clyde Inlet outlet glacier to have receded up-fiord from these sites by ca. 9400 cal. yr BP.

\section{The head of Clyde Inlet}

\section{Radiocarbon ages}

Dozens of moraine segments cross the valley slopes of the fiord head and lower Clyde River valley. These ice limits are commonly radiocarbon datable where in contact with fossiliferous marine deltas. Four prominent deltas at the head of Clyde Inlet have surface elevations that range from $67 \mathrm{~m}$ a.s.l. (outermost) to $62 \mathrm{~m}$ a.s.I. (innermost; Fig. 3). The outermost and innermost deltas are ice-contact features; moraines border their up-valley sides and well-defined distributary channels with intact boulder-levees can be traced from the former ice margins. A bivalve from the $67 \mathrm{~m}$ a.s.l. delta was previously dated to $7940 \pm 130{ }^{14} \mathrm{C}$ yr BP $\quad(8650 \pm 190$ cal.yr BP; Andrews and Drapier, ; site 9, Fig. 3; Table 2). We investigated the stratigraphy of a nearby $6 \mathrm{~m}$ high section of fluvio-deltaic sediments. A paired bivalve from muds at the base of the section yields an age of $8120 \pm 40{ }^{14} \mathrm{C}$ yr BP $(8380 \pm 40 \mathrm{cal}$.yr BP; Fig. 3; Table 2). A second shell fragment from higher in the section yields an age of $8700 \pm 45{ }^{14} \mathrm{C}$ yr BP $(9120 \pm 80 \mathrm{cal}$. yr BP $)$. Because of the age inversion and the fact that the lower sample $(8380 \pm 40 \mathrm{cal} . \mathrm{yr} \mathrm{BP})$ is closer to the original age $(8650 \pm$ $190 \mathrm{cal} . \mathrm{yr}$ BP) obtained nearby, we interpret the $9120 \pm$ $80 \mathrm{cal} . \mathrm{yr} \mathrm{BP}$ shell as having been reworked, and in turn, interpret the $67 \mathrm{~m}$ a.s.l. relative sea level to be ca. $8.5 \pm$ $1.0 \mathrm{cal}$. yr BP. The older bivalve, regardless of possible reworking, requires the fiord head to have been ice-free before $9120 \pm 80 \mathrm{cal} . \mathrm{yr}$ BP.

Emerged marine mud along the lower Clyde River valley drape onto bedrock and the slopes of raised deltas. Sparse remnants of marine mud are mapped on the north side of the Clyde River at sheltered locations up to $58 \mathrm{~m}$ a.s.l. ca. $2 \mathrm{~km}$ up-valley from Clyde Inlet. A Mya truncata bivalve from $58 \mathrm{~m}$ a.s.l. yields a radiocarbon age of $8050 \pm 35{ }^{14} \mathrm{C}$ yr BP $(8330 \pm 40 \mathrm{cal} . \mathrm{yr} \mathrm{BP}$; site 10 , Fig. 3 ; Table 2$)$. Because this sample lies ca. $3 \mathrm{~km}$ up-valley from the $67 \mathrm{~m}$ a.s.l. ice-contact delta and associated ice limit, it provides a minimum age for the ice margin. This age and the ages tied to the $67 \mathrm{ma.s.l}$. ice-contact delta depict an outlet glacier calving in shallow water at $8.5 \pm 1.0 \mathrm{ka}$.

Fossiliferous glacial-marine mud draped onto the foreslope of the $62 \mathrm{~m}$ a.s.l. ice-contact $3 \mathrm{~km}$ up-valley from Clyde Inlet (site 8 , Figs. 3 and 4 ) raises the possibility of obtaining a minimum age of the delta. Three paired, whole Hiatella arctica valves from the bottommost, middle and topmost sections of the sediments yielded radiocarbon ages of $7620 \pm 40{ }^{14} \mathrm{C} \mathrm{yr} \mathrm{BP}$ $\left(7890 \pm 40\right.$ cal. yr BP), $7590 \pm 70{ }^{14} \mathrm{C}$ yr BP $(7860 \pm 70 \mathrm{cal} . \mathrm{yr} \mathrm{BP})$, and $7470 \pm 40{ }^{14} \mathrm{C}$ yr BP $(7730 \pm 50 \mathrm{cal} . \mathrm{yrBP})$, respectively (site 8, Figs 2 and 3; Table 2). The samples provide a close minimum age (ca. $7900 \mathrm{cal} . \mathrm{yr}$ BP) for the ice margin that constructed the $62 \mathrm{~m}$ a.s.l. delta.

A number of fluvio-deltaic terraces were mapped from the river mouth up to ca. $12 \mathrm{~km}$ upstream, where the Clyde River emerges from a bedrock channel. Stratigraphic sections in the terraces show thinly layered, non-bioturbated deposits, indicating deposition in standing water. Seven kilometres inland from Clyde Inlet a fluvio-deltaic terrace at $28 \mathrm{~m}$ a.s.l. contains a $6 \mathrm{~m}$ thick fining-upward sequence. Laminated clay and silt that underlie poorly sorted coarse, pebbly sand contains bivalves that date to $7610 \pm 35{ }^{14} \mathrm{C}$ yr BP $(7880 \pm 40 \mathrm{cal}$. yr BP; site 13, Fig. 3; Table 2). At ca. $3.5 \mathrm{~km}$ inland from Clyde Inlet, sediment coarsens upward, grading from homogeneous clay to laminated silt and fine sand increasing in bed thickness. A bivalve from the base of the section, tied to a $27 \mathrm{~m}$ a.s.l. terrace, is $6600 \pm 35^{14} \mathrm{C}$ yr BP $(6880 \pm 50 \mathrm{cal} . \mathrm{yr} \mathrm{BP}$; site 12 , Fig. 3; Table 2).

\section{Cosmogenic exposure ages}

Five ${ }^{10}$ Be ages were obtained from a transect along the whaleback island ca. $3 \mathrm{~km}$ down-fiord from the Clyde River mouth (site 7; Fig. 2; Table 1); the island lies within the $8.5 \pm 1.0 \mathrm{ka}$ ice margin. The five samples, from up-glacier to down-glacier, are $10.9 \pm 0.4 \mathrm{ka}$ (34 m a.s.I.), $14.5 \pm 0.6 \mathrm{ka}$ (43 m a.s.I.), $13.2 \pm 0.5 \mathrm{ka}$ (43 m a.s.I.), $11.4 \pm 0.5 \mathrm{ka}$ (31 m a.s.l.), and $5.3 \pm 0.5 \mathrm{ka}(12 \mathrm{~m}$ a.s.l.). Upon deglaciation, the island was submerged beneath the sea; the highest sample sites (43 m a.s.I.) emerged relatively quickly following deglaciation (Fig. 5). Yet, the two ${ }^{10} \mathrm{Be}$ ages from these sites are 5000 to $6000 \mathrm{yr}$ older than deglaciation of this site, implying a significant amount of inheritance. The sites around $30 \mathrm{ma.s.l}$. also are older than expected, given that they would have emerged ca. $4000 \mathrm{yr}$ later than their apparent ${ }^{10} \mathrm{Be}$ ages. Inheritance is unexpected at this site because it was probably covered by ice throughout the majority of the last glacial cycle. A laboratory source of error is unlikely because the samples were prepared in three different sample batches, each with their own process blanks that were, in turn, consistent with the laboratory average. That this island was weakly eroded while islands in the outer fiord were more severely eroded remains enigmatic.

Seven boulders ( 1.5 to $3.0 \mathrm{~m}$ in diameter) were sampled from the stable surface of the $62 \mathrm{~m}$ a.s.l. ice-contact delta. The well-rounded boulders are imbricated, indicating no postdepositional movement (Fig. 4), and there is no evidence of permafrost disruption of the delta surface. The ${ }^{10} \mathrm{Be}$ ages range 


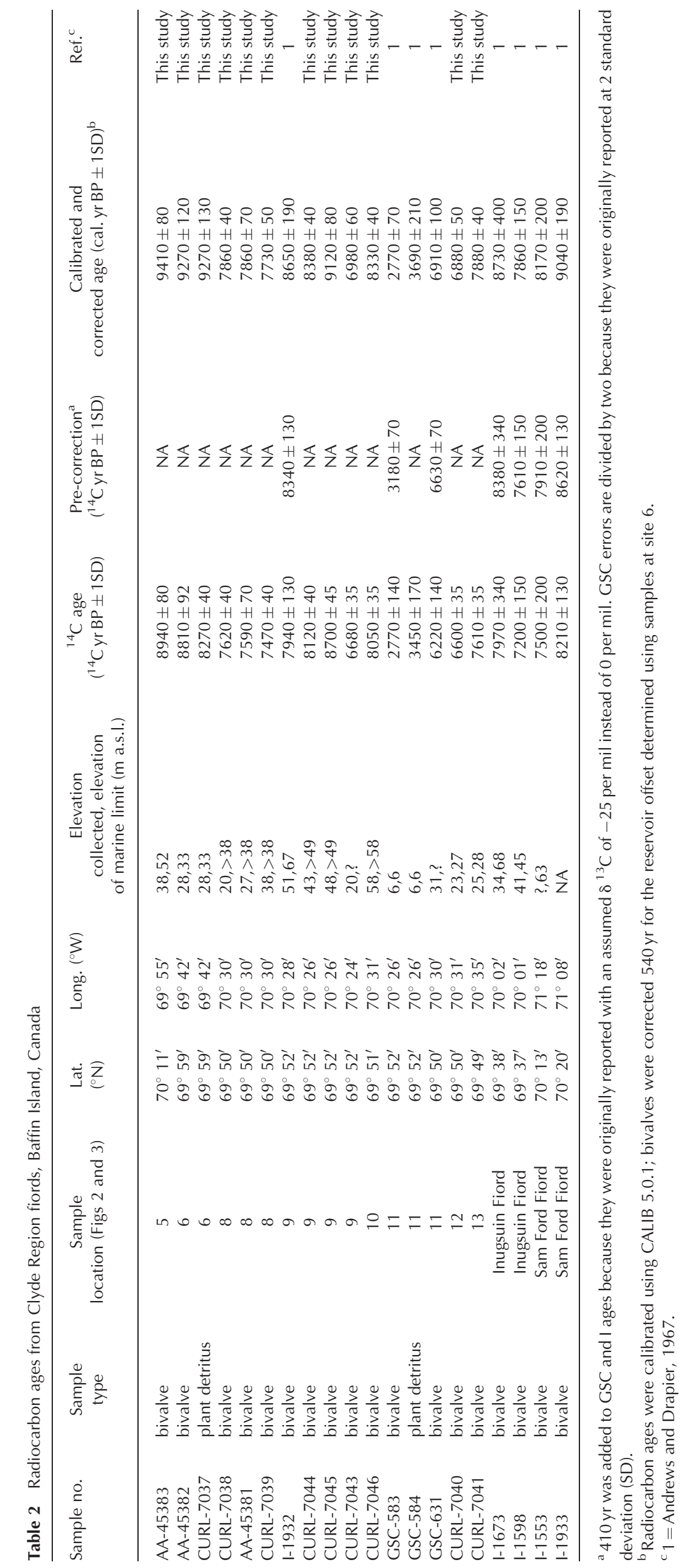




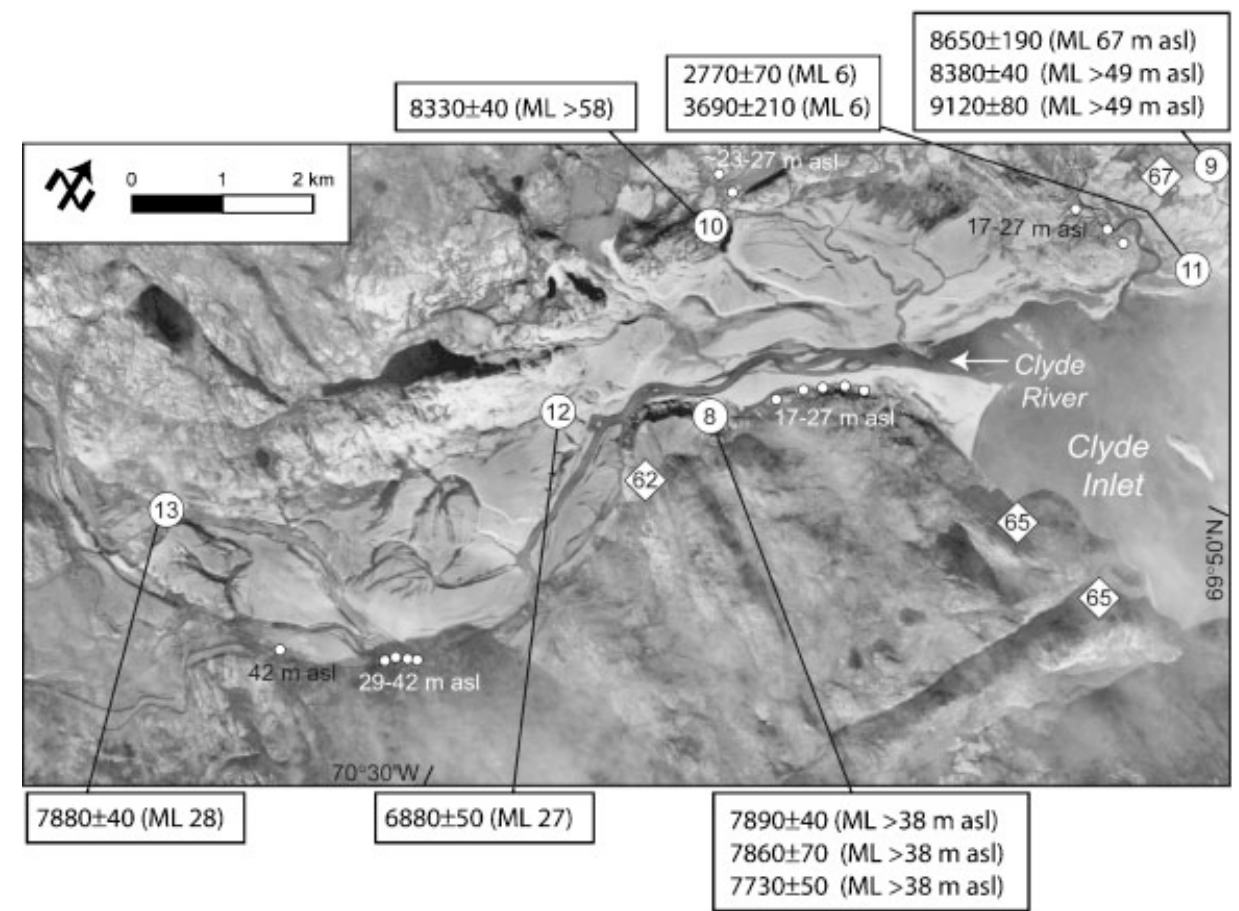

Figure 3 The head of Clyde Inlet showing moraines and raised ice-contact marine deltas. Site numbers in circles refer to ages in Table 2. Small white dots show locations and elevations of emerged marine sediment in metres above sea level (a.s.l.); diamonds mark raised marine deltas with numbers referring to delta surface elevation ( $m$ a.s.l.). $M L=$ marine limit
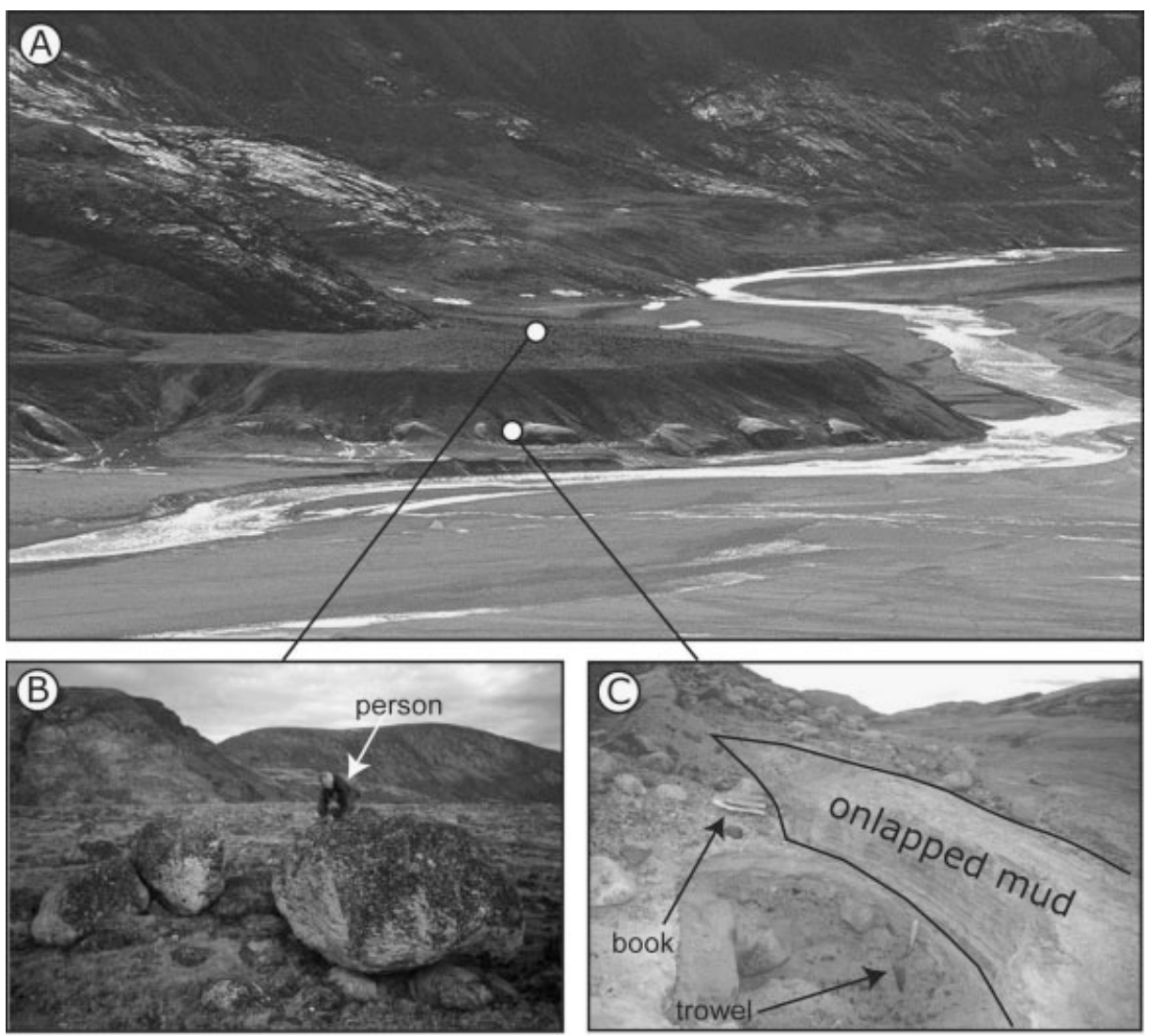

Figure 4 Photographs of the $62 \mathrm{~m}$ a.s.l. delta at the head of Clyde Inlet. (A) The delta showing the Clyde River sweeping around its foreslope and the sections of marine sediments that were onlapped onto the lower part of the delta's foreslope. (B) Rounded boulders on top of the delta surface sampled for cosmogenic exposure dating. Person for scale. (C) Close-up photograph of laminated sediments that were onlapped onto the delta slope; delta gravels can be seen beneath the sediments. Trowel and field book for scale

between $6.9 \pm 0.8$ and $8.1 \pm 0.6 \mathrm{ka}$ and average $7.6 \pm 0.5 \mathrm{ka}$ (Table 1; site 8, Figs 2 and 3). These ages were calculated with a site-specific production rate integrated over time to account for post-depositional emergence and associated elevation change.
The average ${ }^{10} \mathrm{Be}$ age overlaps with the close-minimum radiocarbon age of ca. $7900 \mathrm{cal} . \mathrm{yrBP}$, and supports the $5.1 \pm 0.3{ }^{10} \mathrm{Be}$ atoms $\mathrm{g}^{-1} \mathrm{yr}^{-1}$ production rate of Stone (2000) and Gosse and Stone (2001). 


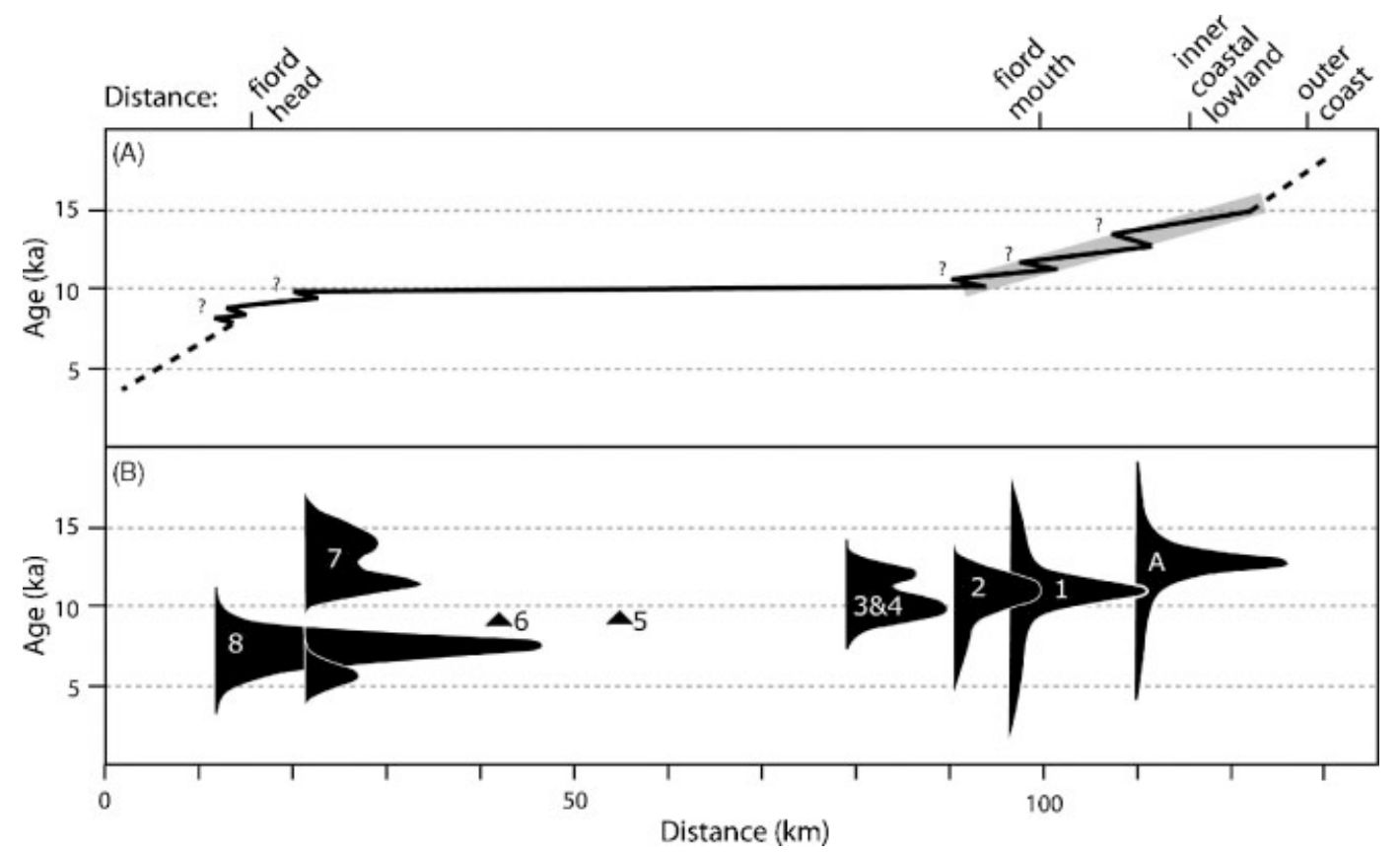

Figure 5 (A) Time-distance diagram of the Laurentide Ice Sheet along Clyde Inlet and adjacent lowlands showing cosmogenic-exposure- and radiocarbon-dated ice-margin fluctuations (dashed where uncertain). Regions where the fluctuating ice margin left behind dozens of moraines and ice-marginal meltwater channels are shown in grey. (B) Probability diagrams of cosmogenic exposure ages from sites in Fig. 2 scaled to the same $x$-axis (arbitrary probability). The probability curve labelled 'A' represents cosmogenic exposure ages from a moraine near the hamlet of Clyde River (Fig. 2) dated by Briner et al. (2005); triangles indicate minimum radiocarbon constraints on deglaciation

\section{Implications}

The glacial history of the northeastern Baffin Island fiords has been recently revised; the LIS is now reconstructed to have filled fiords and crossed coastal lowlands to a margin on the continental shelf during the LGM (Briner et al., 2005, 2006a; Davis et al., 2006). Cosmogenic exposure ages of erratic boulders on the coastal lowlands north and south of the mouth of Clyde Inlet indicate that ice retreated from the continental shelf onto the lowlands between 14 and 16 ka (Fig. 5; Briner et al., 2005; Davis et al., 2006). This time period corresponds with radiocarbon ages (14.4 and $14.8 \mathrm{ka})$ for the oldest of a double-layered ice-rafted debris event in Baffin Bay in sediment cores nearest Clyde Inlet (Andrews et al., 1998). The ice-rafted debris layer is probably the offshore expression of this ice retreat event. The innermost moraine on the Clyde lowland has an average cosmogenic age of $12.5 \pm 0.7(n=3)$, indicating final retreat from the coastal lowlands at that time (Fig. 5; Briner et al., 2005). The lack of focused sampling in this region and the existing resolution in cosmogenic ages in the fiord mouth region prohibits a detailed reconstruction of ice margin positions during the Lateglacial. However, several prominent ice margins in the outer part of the fiord indicate that retreat was not steady, but rather was interrupted by several stillstands and/ or re advances during this time.

The available radiocarbon ages indicate that outer Clyde Inlet deglaciated ca. $10 \mathrm{ka}$, the middle sector deglaciated ca. $9.4 \mathrm{cal} . \mathrm{ka}$, and that the fiord head was ice-free by ca. $9.1 \mathrm{cal}$. ka (Fig. 5). Thus, the $120 \mathrm{~km}$ long fiord deglaciated rapidly within ca. $1000 \mathrm{yr}$. This rapid recession of the Laurentide Ice Sheet, which may correspond to the upper (and thicker) ice-rafted debris layer in Baffin Bay sediment cores near Clyde Inlet (Andrews et al., 1998), was probably a dynamical response as the terminus retreated into deeper waters of central Clyde Inlet. After the ice margin reached the fiord head by ca. $9.1 \mathrm{ka}$, it readvanced and deposited the moraine and associated ice-contact delta at $67 \mathrm{~m}$ a.s.l. at ca. $8.5 \pm 1.0 \mathrm{ka}$. In addition, the outlet glacier deposited at least three other moraines in the fiord head before $8.5 \pm 1.0 \mathrm{ka}$ and after deglaciation of the middle fiord at $9.4 \mathrm{ka}$ (Fig. 2). These fluctuations are probably associated with Cockburn age deposits (between 8.3 and $9.5 \mathrm{ka}$ ) dated elsewhere on Baffin Island (Andrews and Ives, 1978; Miller et al., 2005). Indeed, deposits of similar character and age exist in neighbouring fiords. An ice-contact marine delta at $68 \mathrm{ma}$ a.s.l. dates to $7970 \pm 340{ }^{14} \mathrm{C}$ yr BP (8730 \pm 400 cal. yr BP; Table 2; Løken, 1965) in Inugsuin Fiord (Fig. 1). In Sam Ford Fiord, shells reworked into an end-moraine at the fiord head yield ages of $8210 \pm 130{ }^{14} \mathrm{Cyr} B P \quad(9040 \pm$ 190 cal. yr BP; Table 2; Andrews and Drapier, 1967).

A subsequent readvance at the head of Clyde Inlet, which deposited the moraine and associated ice-contact delta at $62 \mathrm{~m}$ a.s.l. before $7.9 \mathrm{ka}$ and after $8.5 \pm 1.0 \mathrm{ka}$, overlaps with the 8.2 ka cold event first recognised in Greenland ice cores (Alley et al., 1997). An ice-contact delta at 63 ma.s.l. in Sam Ford Fiord is $7500 \pm 200{ }^{14} \mathrm{C}$ yr BP $(8170 \pm 200$ cal. yr BP; Table 2; Andrews and Drapier, 1967), indicating that at least two outlet glaciers of the LIS had readvances possibly associated with the $8.2 \mathrm{ka}$ event. Direct evidence for a local ice cap readvance at $8.2 \mathrm{ka}$ exists on southern Baffin Island (Miller et al., 2005), supporting the idea that the mass balance of the LIS was also altered at this time.

The early Holocene in the eastern Canadian Arctic, as in many places in the Arctic (Kaufman et al., 2004), had the warmest summers of the last $120 \mathrm{ka}$ (Fisher et al., 1995; Dyke et al., 1996; Briner et al., 2006b). Mytilus edulis, which is only found today along the western and southeastern coasts of Baffin Bay (Andrews, 1972; Dyke et al., 1996), is abundant in early Holocene emerged marine mud along northeastern Baffin Island, indicating warmer summer sea surface temperatures in the early Holocene than today (Løken, 1965; Dyke et al., 1996). Thus, moraines along northeastern Baffin Island fiord heads (Baffinland Drift) represent glacier fluctuations that occurred during the warmest period in the last $120 \mathrm{ka}$. Readvances of the 


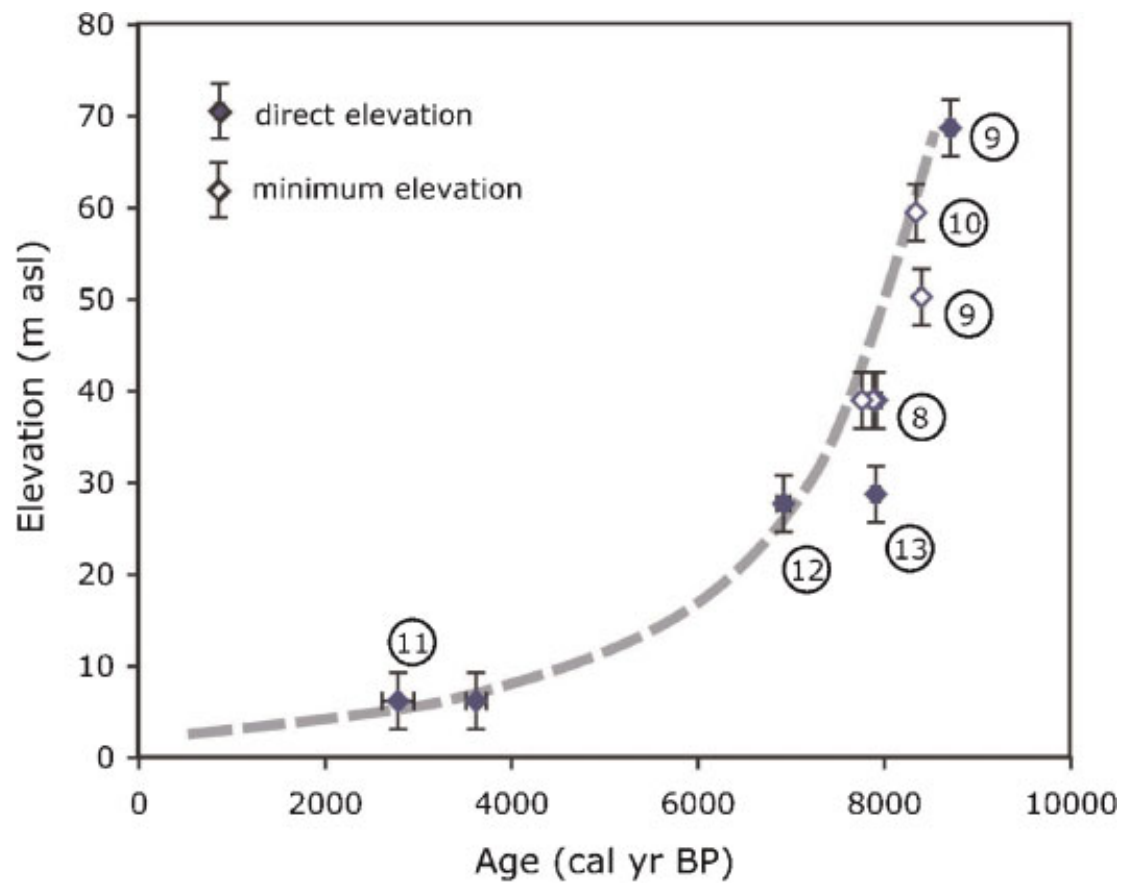

Figure 6 Emergence curve (grey dashed line) for the head of Clyde Inlet based on radiocarbon-dated emerged marine deposits. Fixed $\pm 3 \mathrm{~m}$ uncertainty reflects accuracy of elevation measurements. Sample numbers refer to ages in Table 2

LIS when summer temperatures were warmer than present requires intervals of significant winter precipitation increases during the early Holocene.

The radiocarbon ages reported here, combined with those reported in Andrews and Drapier (1967), are used to create an emergence curve for the head of Clyde Inlet (Fig. 6), a typical emergence curve for Baffin Island fiord heads (Andrews, 1975). The marine limit at the fiord head ( $67 \mathrm{~m}$ a.s.l.) is only slightly higher than in the outer fiord (ca. $50 \mathrm{~m}$ a.s.l.), but much higher than along the outer coast is $22 \mathrm{~m}$ a.s.l. (Briner et al., 2005). Because rapid deglaciation of the fiord would suggest a steeper gradient of the marine limit between the outer and inner fiord, we speculate that significant rebound (restrained) occurred at the fiord head while it was still occupied by ice during the earliest Holocene.

\section{Conclusions}

Recent ice sheet reconstructions depict the northeastern LIS extending onto the continental shelf during the LGM (Dyke et al., 2002, 2003; Miller et al., 2002; Briner et al., 2005). Our new data for deglaciation along Clyde Inlet, a fiord system similar to dozens of others along northeastern Baffin Island, suggest that ice retreated from the continental shelf onto the coast lowlands ca. $15 \mathrm{ka}$, and retreated from the inner coastal lowlands by ca. $13 \mathrm{ka}$. The outlet glacier in Clyde Inlet fluctuated in the fiord mouth until ca. $10 \mathrm{ka}$, and rapidly retreated through the middle fiord by ca. $9.4 \mathrm{ka}$, and was behind the fiord head before $9.1 \mathrm{ka}$. Two readvances recorded at the head of Clyde Inlet (and in neighbouring fiord heads) occurred ca. $8.5 \mathrm{ka}$ and shortly before $7.9 \mathrm{ka}$, overlapping with the Cockburn Substage and possibly the $8.2 \mathrm{ka}$ event, respectively. Our understanding of ice-sheet response to the $8.2 \mathrm{ka}$ event can be improved by further characterising the response of Baffin Island glaciers during this interval. Early Holocene ice margin readvances occurred during generally the warmest summers of the last ca. $120 \mathrm{kyr}$. Some of these readvances may have been associated with brief cold events, like the $8.2 \mathrm{ka}$ event, but others do not have recognised comparable cold event drivers. These readvances were most likely driven by increased winter precipitation, possibly associated with the penetration of relatively warm waters into Baffin Bay and the steering of southerly storm systems into the Arctic.

Acknowledgements We thank B. Clarke, P. T. Davis, J. Landvik, A. Kettner, J. Leonard, and M. Robinson for assistance in the field, and J. Turnbull for preparation of radiocarbon samples. We thank the Nunavut Research Institute and the people of Clyde River, particularly J. Qillaq and J. Hainnu, for assistance with field logistics. J. T. Andrews, J. Landvik, Y. Axford and R. Coulthard provided stimulating discussions on the deglaciation history of Baffin Island. J. T. Andrews, L. Farmer, W. F. Manley and T. Pfeffer commented on an earlier form of this manuscript. We are grateful for formal reviews by J. Smith, M. Retelle and L. Owen and additional comments by D. Rodbell. This work was funded by the National Science Foundation, Arctic Natural Sciences Program (OPP-0004455 and OPP-0138010. This work was performed under the auspices of the U.S. Department of Energy by the University of California, Lawrence Livermore National Laboratory under contract number W-7405-Eng-48.

\section{References}

Alley RB, Mayewski PA, Sowers T, Stuiver M, Taylor KC, Clark PU. 1997. Holocene climatic instability: a prominent widespread event 8200 yr ago. Geology 25: 483-486.

Andrews JT. 1972. Recent and fossil growth rates of marine bivalves, Canadian Arctic, and Late-Quaternary Arctic marine environments. Palaeogeography, Palaeoclimatology, Palaeoecology 11: 157-176.

Andrews JT. 1975. Glacial Systems: An Approach to Glaciers and their Environments. Wadsworth: Belmont.

Andrews JT, Barnett DM. 1979. Holocene (Neoglacial) moraine and proglacial lake chronology, Barnes Ice Cap, Canada. Boreas 8: 341-358. 
Andrews JT, Drapier L. 1967. Radiocarbon dates obtained through Geographical Branch field observations. Geographical Bulletin 9: 115-162.

Andrews JT, Ives JD. 1978. 'Cockburn' nomenclature and the late Quaternary history of the eastern Canadian Arctic. Arctic and Alpine Research 20: 617-633.

Andrews JT, Kirby ME, Aksu A, Barber DC, Meese D. 1998. Late Quaternary detrital carbonate (DC-) layers in Baffin Bay marine sediments (67 degrees-74 degrees N): correlation with Heinrich events in the North Atlantic? Quaternary Science Reviews 17: 1125-1137.

Bierman PR, Caffee M. 2001. Slow rates of rock surface erosion and sediment production across the Namib Desert and Escarpment, southern Africa. American Journal of Science 301: 326-358.

Bierman PR, Marsella KA, Patterson C, Davis PT, Caffee M. 1999. Mid-Pleistocene cosmogenic minimum-age limits for preWisconsinan glacial surfaces in southwestern Minnesota and southern Baffin Island: a multiple nuclide approach. Geomorphology 27: 25-39.

Boyer SJ, Pheasant DR. 1974. Delimitation of weathering zones in the fiord area of eastern Baffin Island, Canada. Geological Society of America Bulletin 85: 805-810.

Briner JP. 2003. Laurentide Ice Sheet dynamics and chronology of the Clyde Region, northeastern Baffin Island, Canada. Ph.D. dissertation, University of Colorado, Boulde.

Briner JP, Miller GH, Davis PT, Bierman PR, Caffee M. 2003. Last Glacial Maximum ice sheet dynamics in Arctic Canada inferred from young erratics perched on ancient tors. Quaternary Science Reviews 22: 437-444.

Briner JP, Miller GH, Davis PT, Finkel R. 2005. Cosmogenic exposure dating in arctic glacial landscapes: implications for the glacial history of northeastern Baffin Island, Arctic Canada. Canadian Journal of Earth Sciences 42: 67-84.

Briner JP, Miller GH, Davis PT, Finkel RC. 2006a. Cosmogenic radionuclides from fiord landscapes support differential erosion by overriding ice sheets. Geological Society of America Bulletin 118: 406-420.

Briner JP, Michelutti N, Francis DR, Miller GH, Axford Y, Wooller MJ, Wolfe AP. 2006b. A multi-proxy lacustrine record of Holocene climate change on northeastern Baffin Island, Arctic Canada. Quaternary Research 65: 431-442.

Coulthard RD. 2003. The glacial and sea level history of the Aston Lowlands, east-central Baffin Island, Nunavut, Canada. M.Sc. thesis, University of Colorado, Boulder.

Davis PT, Briner JP, Coulthard RD, Finkel RC, Miller GH. 2006. Preservation of arctic landscapes overridden by cold-based ice sheets. Quaternary Research 65: 156-163.

Dyke AS, Prest VK. 1987. Late Wisconsin and Holocene history of the Laurentide Ice Sheet. Geographie Physique et Quaternaire 41: 237-263.

Dyke AS, Dale JE, McNeely RN. 1996. Marine molluscs as indicators of environmental change in glaciated North America and Greenland during the last 18,000 years. Géographie Physique et Quaternaire 50: 125-184.

Dyke AS, Andrews JT, Clark PU, England JH, Miller GH, Shaw J, Veillette JJ. 2002. The Laurentide and Innuitian ice sheets during the Last Glacial Maximum. Quaternary Science Reviews 21: 9-31.

Dyke AS, Moore A, Robinson L. 2003. Deglaciation of North America. Geological Survey of Canada, Open File 1574.
Falconer G, Andrews JT, Ives JD. 1965. Late-Wisconsin end moraines in northern Canada. Science 147: 608-610.

Fisher DA, Koerner RM, Reeh N. 1995. Holocene climatic records from Agassiz Ice Cap, Ellesmere Island, N.W.T., Canada. The Holocene 5: 19-24.

Gosse JC, Stone JO. 2001. Terrestrial cosmogenic nuclide methods passing milestones toward paleo-altimetry. Eos (Transactions, American Geophysical Union) 82: 82, 86, 89.

Hooke R LeB. 1976. Pleistocene ice at the base of the Barnes Ice Cap, Baffin Island, N.W.T., Canada. Journal of Glaciology 17: 174-1188.

Ives JD. 1978. The maximum extent of the Laurentide ice sheet along the east coast of North America during the last glaciation. Arctic 31: 24-53.

Ives JD, Andrews JT. 1963. Studies in the physical geography of north-central Baffin Island, N.W.T. Geographical Bulletin 5: 5-48.

Kaufman DS, Ager TA, Anderson NJ, Anderson PM, Andrews JT, Bartlein PT, Brubaker LB, Coats LL, Cwynar LC, Duvall ML, Dyke AS, Edwards ME, Eisner WR, Gajewski K, Geirsdottir A, Hu FS, Jennings $A E$, Kaplan MR, Kerwin MW, Lozhkin AV, MacDonald GM, Miller GH, Mock CJ, Oswald WW, Otto-Bliesner BL, Porinchu DF, Ruhland K, Smol JP, Steig EJ, Wolfe BB. 2004. Holocene thermal maximum in the western Arctic (0-180 degrees W). Quaternary Science Reviews 23: 2059-2060.

Kohl CP, Nishiizumi K. 1992. Chemical isolation of quartz for measurement of in-situ-produced cosmogenic nuclides. Geochimica et Cosmochimica Acta 56: 3583-3587.

Lal D. 1991. Cosmic ray labeling of erosion surfaces; in situ nuclide production rates and erosion models. Earth and Planetary Science Letters 104: 424-439.

Løken OH. 1965. Postglacial emergence at the south end of Inugsuin Fiord, Baffin Island, N.W.T. Geographic Bulletin 7: 243-258.

Miller GH. 1976. Anomalous local glacier activity, Baffin Island, Canada: Paleoclimatic implications. Geology 4: 502-504.

Miller GH, Andrews JT, Short SK. 1977. The last interglacial-glacial cycle, Clyde foreland, Baffin Island, N. W. T.: stratigraphy, biostratigraphy, and chronology. Canadian Journal of Earth Sciences 14: 2824-2857.

Miller GH, Wolfe AP, Steig EJ, Sauer PE, Kaplan MR, Briner JP. 2002. The Goldilocks dilemma: big ice, little ice, or 'just right' ice in the Eastern Canadian Arctic. Quaternary Science Reviews 21: 33-48.

Miller GH, Wolfe AP, Briner JP, Sauer PE, Nesje A. 2005. Holocene glaciation and climate evolution of Baffin Island, Arctic Canada. Quaternary Science Reviews 24: 1703-1721.

Mode WN. 1980. Quaternary stratigraphy and palynololgy of the Clyde Foreland, Baffin Island, N.W.T., Canada. Ph.D. dissertation, University of Colorado, Boulder.

Smith JE. 1965. Outer Clyde-Ayr uplands, field report. Canada Dept. Energy, Mines and Resources, Geographical Branch.

Smith JE. 1966. Sam Ford Fiord: a study in deglaciation. M.Sc. thesis, McGill University, Montreal.

Steig EJ, Wolfe AP, Miller GH. 1998. Wisconsinan refugia and the glacial history of eastern Baffin Island, Arctic Canada: coupled evidence from cosmogenic isotopes and lake sediments. Geology 26: $835-838$

Stone JO. 2000. Air pressure and cosmogenic isotope production. Journal of Geophysical Research 105: 23,753-23,759.

Stuiver M, Reimer PJ, Reimer RW. 2005. CALIB 5.0. [WWW program and documentation]. 